УДК 54.05

\title{
ИЗУЧЕНИЕ СУЛЬФАТОВ ЦЕЛЛЮЛОЗЫ МЕТОДОМ РЕНТГЕНОВСКОЙ ФОТОЭЛЕКТРОННОЙ СПЕКТРОСКОПИИ
}

\author{
() А.С. Романченко ${ }^{I}$, А.В. Левданский, В.А. Левданский ${ }^{1,2}$, Б.Н. Кузнецов \\ ${ }^{1}$ Институт химии и химической технологии СО РАН, Академгородок, 50/24, \\ Красноярск, 660036 (Россия), e-mail: inm@icct.ru \\ ${ }^{2}$ Сибирский феедеральный университет, пр. Свободный, 79, Красноярск, \\ 660041 (Россия)
}

\begin{abstract}
Методом рентгеновской фотоэлектронной спектроскопии изучены образцы микрокристаллической целлюлозы (МКЦ) до и после сульфатирования. Установлено, что при взаимодействии МКЦ с хлорсульфоновой кислотой в диоксане происходит введение сульфатных групп в структуру целлюлозы. Содержание серы в сульфатированной МКЦ составляет от 4,0 до 9,7\% ат., причем сера находится в сульфатной форме. Сопоставлено содержание серы на поверхности и в объеме образцов сульфатов МКЦ. Наблюдаемое различие в форме 1s линий углерода в спектрах образцов исходной и сульфатированной МКЦ указывает на изменение электронного состояния части атомов углерода после сульфатирования.

Ключевые слова: микрокристаллическая целлюлоза, сульфатирование, хлорсульфоновая кислота, диоксан, сульфаты целлюлозы, электронная спектроскопия для химического анализа.
\end{abstract}

Работа выполнена при финансовой поддержке РФФИ (проекты № 12-03-31433 и № 12-03-93117) и

ККФПНиНТД (дополнительное соглашение № 07/12 от 04.09.2012).

\section{Введение}

Одними из перспективных для практического использования веществ растительного происхождения являются сульфаты целлюлозы (СЦ). Они могут применяться как антикоагулянты крови, иммуномодуляторы, антивирусные препараты, сорбенты токсичных металлов [1, 2].

В настоящее время основным антикоагулянтом, использующимся в клинической практике, является полисахарид гепарин, выделяемый из сырья животного происхождения. Однако гепарин может быть заражен патогенами и вирусами. Поэтому разработка простых способов получения и физико-химическое исследование сульфатов целлюлозы (СЦ) в качестве альтернативы гепарину является актуальной задачей.

В работе [3] описаны методы получения и свойства сульфатов целлюлозы высоких степеней замещения на основе хлопковой микрокристаллической целлюлозы. Сульфатирование микрокристаллической целлюлозы серной кислотой в присутствии $\boldsymbol{H}$-пропанола и применение аминосульфоновой кислоты приве-

Романченко Александр Сергеевич - кандидат химических наук, e-mail:inm@icct.ru

Левданский Александр Владимирович - научный сотрудник, тел.: (391) 249-55-84, e-mail:inm@icct.ru

Левданский Владимир Александрович - ведущий научный сотрудник, доктор химических наук, тел.: (391) 249-55-84, e-mail:inm@icct.ru

Кузнечов Борис Николаевич - первый заместитель директора Института химии и химической технологии СО РАН, профессор, доктор химических наук, заведующий кафедрой аналитической и органической химии Сибирского федерального университета, тел.: (391) 249-48-94, e-mail: bnk@icct.ru, inm@icct.ru ло к продуктам с низкой степенью этерификации, только частично растворимым в воде. Высоких степеней замещения (С3) авторам удалось достичь, применив комплекс $\mathrm{SO}_{3}$ - пиридин при температурах реакции 80-90 ${ }^{\circ} \mathrm{C}$. Дальнейшее увеличение температуры реакции наряду с ростом С3 приводило к падению приведенной вязкости ( $\eta_{\text {пр }}$ ) для растворов СЦ, что свидетельствовало о процессах деструкции полимера. К недостаткам следует отнести сложность выделения целевого продукта, а также использование токсичного пиридина. В работе [4] сульфатирование

\footnotetext{
* Автор, с которым следует вести переписку
} 
МКЦ было проведено комплексом $\mathrm{ClSO}_{3} \mathrm{H}$-диметилформамид при различных условиях и дало в результате продукты с различной С3. Значения С3 лежали в интервале между 0,6-1,7 и возрастали с увеличением концентрации сульфатирующего агента. Средняя молекулярная масса колебалась в пределах 12-27 кДа. Полученная натриевая соль сульфата целлюлозы нуждалась в диализе и характеризовалась широкими распределениями молекулярных масс. В большинстве продуктов наблюдалась полидисперсность из-за гидролиза главной цепи целлюлозы в кислотной среде. Данные ИК, ЯМР-спектрометрии и элементного анализа показали, что сульфатирование произошло преимущественно при $\mathrm{C}_{6}$, частично при $\mathrm{C}_{2}$ и ничтожно мало при $\mathrm{C}_{3}$. Исследования антикоагулянтной активности показали перспективность разработки новых препаратов на основе натриевой соли сульфата целлюлозы.

Нами был разработан новый способ сульфатирования микрокристаллической целлюлозы в мягких условиях - хлорсульфоновой кислотой в диоксане [5]. Реакция сульфатирования МКЦ хлорсульфоновой кислотой в диоксане начинается в двухфазной, а заканчивается в однофазной системе практически полным сульфатированием ОН групп при $\mathrm{C}_{6}$ атомах глюкопиранозных звеньев МКЦ. С помощью элементного анализа, ИК и ЯМР ${ }^{13} \mathrm{C}$ спектроскопии проведено исследование строения и свойств исходной МКЦ и ее сульфатированных производных. Показано, что полученные сульфаты целлюлозы являются антикоагулянтами прямого действия, так как удлиняют время свертывания плазмы человека in vitro в коагулологических тестах $[6,7]$.

Известно, что антикоагулянтная активность сульфатов полисахаридов зависит от многих факторов: степени сульфатирования, характера расположения сульфатных групп, молекулярной массы полисахарида и др. [8]. Для установления взаимосвязи между строением и биологической активностью необходимо детальное физико-химическое исследование образцов сульфатов МКЦ.

В настоящей работе впервые методом рентгеновской фотоэлектронной спектроскопии (РФЭС) изучены состав и строение сульфатированных производных, полученных новым способом - обработкой хлорсульфоновой кислотой в диоксане образцов МКЦ из соломы пшеницы и древесины осины.

\section{Экспериментальная часть}

Получение образцов микрокристаллической целлюлозы осуществляли экологически безопасным способом - окислительной делигнификацией соломы пшеницы и древесины осины пероксидом водорода в среде уксусная кислота - вода в присутствии сернокислотного катализатора по методикам, описанным в работах $[9,10]$. Также использовали микрокристаллическую целлюлозу Vivapur® Туре 101 производства JRS Pharma (Вайссенборн, Германия). Некоторые характеристики использованных образцов МКЦ приведены в таблице 1.

Сульфатирование МКЦ осуществляли хлорсульфоновой кислотой в трехгорлой колбе объемом 100 мл, снабженной мешалкой, термометром и капельной воронкой. В колбу загружали 1 г МКЦ, предварительно высушенной до постоянной массы при температуре $103-105^{\circ} \mathrm{C}$, заливали 30 мл 1,4-диоксана и перемешивали при комнатной температуре в течение 4 ч. Затем в смесь при охлаждении и интенсивном перемешивании по каплям вносили хлорсульфоновую кислоту и перемешивали при $20-50{ }^{\circ} \mathrm{C}$ в течение 3-4 ч. После этого реакционную смесь при перемешивании выливали в стакан, содержащий 100 мл $50 \%$ водноэтанольного раствора и $3 \%$ гидроксида натрия. Образовавшуюся натриевую соль сульфата целлюлозы отделяли фильтрованием, промывали на фильтре $96 \%$ этанолом и сушили в вакууме.

Содержание серы в сульфате целлюлозы определяли по модифицированной методике [11] сжиганием в токе кислорода с последующим поглощением продуктов сжигания пероксидом водорода и титрованием щелочью в присутствии индикатора метилового красного.

Степень замещения в образцах сульфатов целлюлозы $C 3$ находили по уравнению

$$
C 3=\frac{162 \times S_{\text {масс }}}{3200-102 \times S_{\text {масс }}}
$$

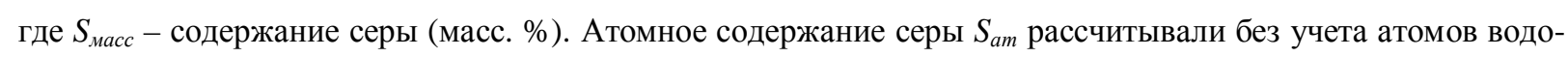
рода по уравнению

$$
S_{a m}=\frac{N_{S}}{N} \times 100 \%,
$$

где $N_{S}$ - число атомов серы, $N$ - общее число атомов в элементарном звене полимера. При этом предполагалось, что строение элементарного звена полимера соответствует формуле $\left[\mathrm{C}_{6} \mathrm{H}_{7} \mathrm{O}_{2}(\mathrm{OH})_{3-\mathrm{C} 3}\left(\mathrm{OSO}_{3} \mathrm{Na}\right)_{\mathrm{C} 3}\right]_{\mathrm{n}}$. 
Таблица 1. Характеристики образцов МКЦ

\begin{tabular}{l|c|c|c|c}
\hline \multicolumn{1}{c|}{ Образец } & $\begin{array}{c}\text { Степень полимери- } \\
\text { зации (СП) }\end{array}$ & $\begin{array}{c}\text { Степень кристал- } \\
\text { личности (СК) }\end{array}$ & $\begin{array}{c}\text { Содержание оста- } \\
\text { точного лигнина, \% }\end{array}$ & $\begin{array}{c}\text { Содержание } \\
\text { гемицеллюлоз, \% }\end{array}$ \\
\hline МКЦ из соломы пшеницы & 200 & 0,66 & 0,1 & 5,5 \\
МКЦ из древесины осины & 210 & 0,71 & 0,1 & 5,3 \\
МКЦ промышленная & 249 & 0,75 & не обнаружено & 5,2 \\
\hline
\end{tabular}

Для съемки рентгеновских фотоэлектронных спектров использовали образцы натриевой соли сульфата целлюлозы в виде порошка и пленок. Прозрачные пленки сульфатированных образцов МКЦ получали испарением 6-7\% водных растворов на гладкой стеклянной подложке. Спектры снимались на спектрометре SPECS (SPECS Gmbh, Германия) в сверхвысоком вакууме с давлением не выше $1 \cdot 10^{-9}$ МБар. Для проведения экспериментов порошок или пленка наносились на углеродную ленту, приклеенную к молибденовой подложке. Источником рентгеновского излучения служила рентгеновская трубка с магниевым анодом $(\mathrm{Mg} \mathrm{K \alpha}, \mathrm{E}=1253,6$ эВ). Мощность излучения 180 Вт, напряжение на трубке 12,5 кВ. Для снятия электростатической подзарядки образцов применяли облучение медленными электронами. Анализ фотоэлектронов по энергиям выполняли с помощью полусферического энергоанализатора PHOIBOS 1500 MCD9, управление энергоанализатором осуществляли программой SpecsLab2. Обзорные спектры получали с шагом 0,5 эВ и энергией пропускания (PassEnergy) - 20 эВ, затем отдельные линии для каждого элемента $\mathrm{O}, \mathrm{C}, \mathrm{S}$, а также $\mathrm{Na}, \mathrm{Si}$ и $\mathrm{Ca}$ с параметрами: энергия пропускания -8 эВ, шаг $=0,05$ эВ. Обработка спектров проводилась в программе CasaXPS 3,0, разложение выполнялось Гауссовско-Лоренцевскими компонентами.

Определение относительного содержания элементов (кроме Н и Не) в зоне анализа (глубина анализа 2-3 нм) осуществляли по интегральным интенсивностям РФЭС-линий, откорректированным на соответствующие коэффициенты атомной чувствительности.

\section{Результаты и обсуждение}

Обзорные спектры и атомный состав. Обзорные рентгеновские фотоэлектронные спектры образцов МКЦ из соломы пшеницы и древесины осины, а также промышленной МКЦ приведены на рисунках 1-3.

Основные линии, присутствующие в спектрах, соответствуют углероду и кислороду. Для спектра МКЦ, полученной из соломы пшеницы, характерно наличие линии кремния, присутствующего в небольшом количестве в составе исходного сырья [12]. Данные по атомному составу образцов МКЦ, полученные из анализа рентгеновских фотоэлектронных спектров, приведены в таблице 2.

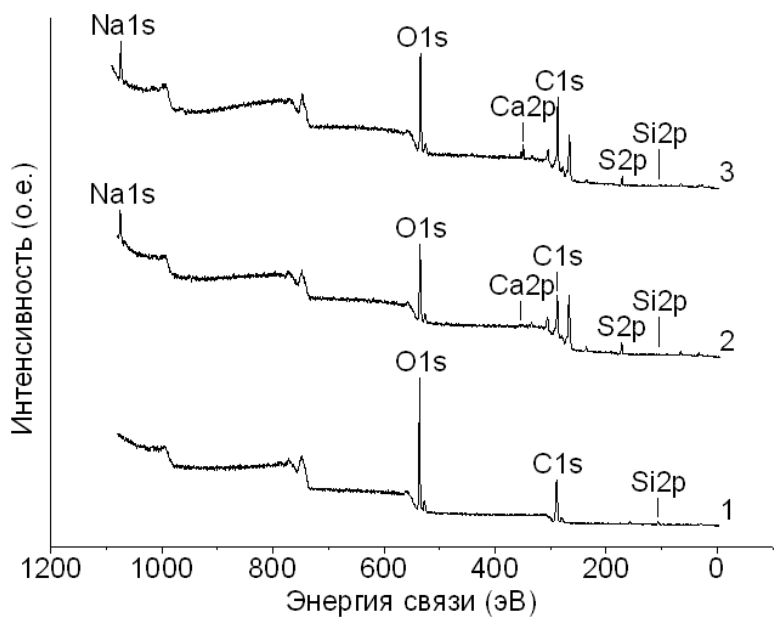

Рис. 1. РФЭС-спектры исходной МКЦ из соломы пшеницы (1) и сульфатированных образцов МКЦ из соломы пшеницы (2 - порошок, 3 - пленка)

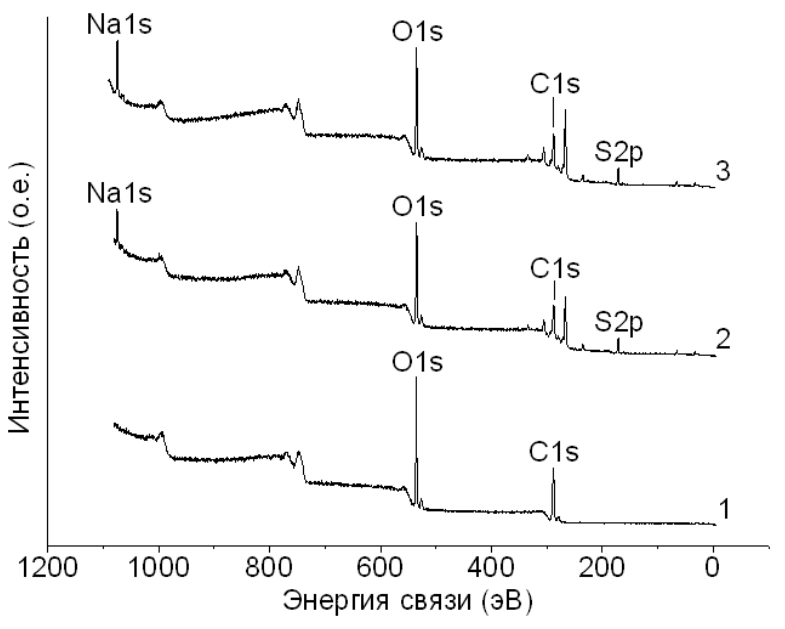

Рис. 2. РФЭС спектры исходной МКЦ из древесины осины (1) и сульфатированных образцов МКЦ из древесины осины (2 - порошок, 3 - пленка) 

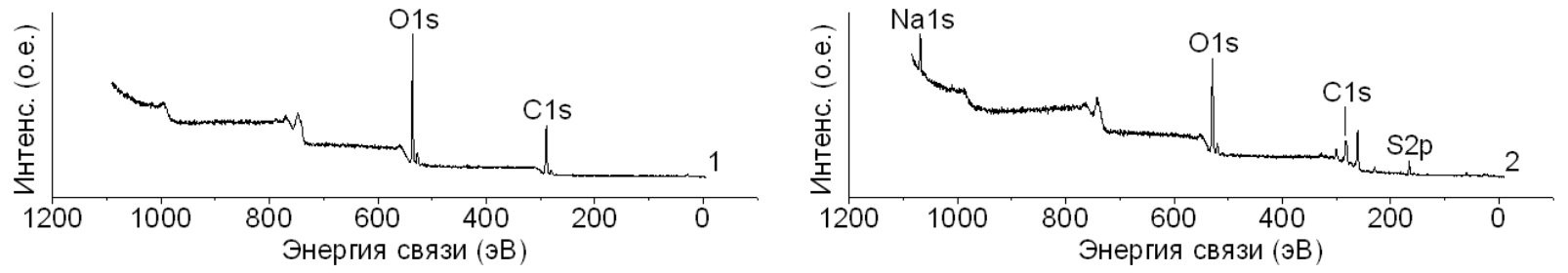

Рис. 3. РФЭС спектры промышленной МКЦ (1) и сульфатированного образца промышленной МКЦ (2)

По данным РФЭС, различные образцы МКЦ несколько отличаются по содержанию углерода и кислорода. МКЦ из соломы пшеницы содержит меньше углерода по сравнению с МКЦ из древесины осины (соответственно 53,3 и 64,4 \% ат.) и больше кислорода (соответственно 43,8 и 35,6 \% ат.). В промышленной МКЦ содержание углерода составляет 57,3\% ат., а кислорода - 42,7\% ат.

Сульфатирование МКЦ хлорсульфоновой кислотой в диоксане и последующее выделение сульфата целлюлозы в виде натриевой соли приводит к введению сульфатных групп в структуру МКЦ, в связи с чем в спектрах появляются соответствующие линии, отвечающие сере и натрию (соответственно при 168 и 1070 эВ) (рис. 1-3). На поверхности образцов сульфатированной МКЦ из соломы пшеницы также присутствуют небольшие количества кремния и появляются следы кальция. Отсутствие кальция в поверхностном слое исходной МКЦ соломы пшеницы, вероятно, объясняется его неравномерным распределением в образце.

По данным анализа атомного состава образцов, содержание серы в поверхностном слое сульфатированной МКЦ из соломы пшеницы составляет 4,0-5,6\% ат., сульфатированной МКЦ из древесины осины 7,5-9,7\% ат., а сульфатированной промышленной МКЦ - 7,9\% ат. Соотношение атомных концентраций натрий / сера на поверхности образцов близко к 1.

Сопоставление данных РФЭС и химического анализа. Результаты сопоставления атомного содержания серы в СЦ, определенного химическим анализом и из рентгеновских фотоэлектронных спектров, представлены в таблице 3 .

Как следует из приведенных в таблице 3 данных, объемное содержание серы, определенное химическим анализом, в образцах СЦ из древесины осины и промышленной МКЦ слабо отличается от поверхностного, определенного методом РФЭС, что свидетельствует о достаточно однородном распределении атомов серы в этих образцах. В сульфатах МКЦ из соломы пшеницы содержание серы на поверхности несколько меньше, чем в объеме.

Таблица 2. Элементный состав образцов исходной и сульфатированной МКЦ по данным РФЭС

\begin{tabular}{l|c|c|c|c|c|c}
\hline \multicolumn{1}{c|}{ Образец } & \multicolumn{3}{c}{ Состав, \% ат. } \\
\cline { 2 - 7 } & $\mathrm{C}$ & $\mathrm{O}$ & $\mathrm{S}$ & $\mathrm{Na}$ & $\mathrm{Si}$ & $\mathrm{Ca}$ \\
\hline МКЦ из соломы пшеницы & 53,3 & 43,8 & 0 & 0 & 2,9 & 0 \\
МКЦ из древесины осины & 64,4 & 35,6 & 0 & 0 & 0 & 0 \\
МКЦ промышленная & 57,3 & 42,7 & 0 & 0 & 0 & 0 \\
Сульфат МКЦ из соломы пшеницы & 53,8 & 33,3 & 5,6 & 5,3 & 1,4 & 0,6 \\
Пленка сульфата МКЦ из соломы пшеницы & 52,4 & 34,4 & 4,0 & 5,1 & 1,8 & 2,3 \\
Сульфат МКЦ из древесины осины & 46,1 & 39,5 & 7,5 & 6,8 & 0 & 0 \\
Пленка сульфата МКЦ из древесины осины & 43,0 & 38,6 & 9,7 & 8,6 & 0 & 0 \\
Сульфат промышленной МКЦ & 45,9 & 39,0 & 7,9 & 7,2 & 0 & 0 \\
\hline
\end{tabular}

Таблица 3. Содержание серы в образцах сульфатированной МКЦ по данным химического анализа и РФЭС

\begin{tabular}{l|c|c}
\hline \multicolumn{1}{c|}{ Образец } & \multicolumn{2}{|c}{ Содержание серы, \% ат. } \\
\cline { 2 - 3 } & РФЭС & Химический анализ \\
\hline Сульфат МКЦ из соломы пшеницы & 5,6 & 8,5 \\
Пленка сульфата МКЦ из соломы пшеницы & 4,0 & 7,6 \\
Сульфат МКЦ из древесины осины & 7,5 & 7,7 \\
Пленка сульфата МКЦ из древесины осины & 9,7 & 8,2 \\
Сульфат промышленной МКЦ & 7,9 & \\
\hline
\end{tabular}


РФЭC $S 2 p$ линии серы. Для всех сульфатированных образцов МКЦ рентгеновские фотоэлектронные спектры 2 р линий серы имеют одинаковый вид (рис. 4-6).

Спектр разлагается на две компоненты дублета $\mathrm{S} 2 \mathrm{p}_{3 / 2}$ (энергия связи 168,6 эB) и S2 $\mathrm{p}_{1 / 2}$ (энергия связи 169,8 эВ), что соответствует шестивалентной сере, связанной с кислородом, в данном случае это $\mathrm{OSO}_{3} \mathrm{Na}$ группы. Поскольку иных компонент в спектрах не наблюдается, правомерно предположить, что в пределах анализируемого слоя (порядка 2 нм) сера присутствует только в сульфатной форме.

РФЭC Cls линии углерода. Наблюдаемые различия в форме 1s линий углерода в спектрах образцов исходной и сульфатированной МКЦ указывают на изменение химического состояния атомов углерода в процессе сульфатирования. Спектры РФЭС 1s линии углерода исследованных образцов представлены на рисунках 7-9.

Полученные спектры состоят из нескольких компонент с различной энергией связи, соответствующих различным атомам углерода в целлюлозе. Результаты разложения РФЭС спектров 1s линий углерода, энергии связи разных форм углерода и их относительный вклад приведены в таблице 4.

В соответствии с литературными данными [13], интенсивный пик $\mathrm{C}_{1}$ при 284,8 эВ относится к углероду, связанному с атомами углерода и водорода, т.е. углероду в $\mathrm{sp}^{3}$-гибридизации, вероятно он обусловлен наличием углеводородных загрязнений на поверхности СЦ. Компоненты с большей энергией связи соответствуют углероду, химически связанному с кислородом. Пик с энергией связи 286,4-286,6 эВ, отмеченный как $\mathrm{C}_{2}$, может принадлежать сигналам атомов углерода гидроксильных, либо эфирных групп целлюлозы (-C-O-), а пик $\mathrm{C}_{3}$ при 287,9-288,4 эВ - полуацетальным связям цепи целлюлозы (-O-C-O-) и углероду карбонильной $(-\mathrm{C}=\mathrm{O})$ и карбоксильной $(-\mathrm{O}-\mathrm{C}=\mathrm{O})$ групп. Четвертый пик, имеющий энергию связи около 290,4 эВ, отвечает оже-линии натрия, которая имеет сложную структуру и накладывается на линию C1s.

Сульфатирование МКЦ в системе хлорсульфоновая кислота - диоксан в течение 3-4 ч приводит к понижению вклада компоненты $\mathrm{C}_{2}$, а также смещению до 284,5 эВ и увеличению в 1,5-2 раза компоненты $\mathrm{C}_{1}$. Эта компонента может принадлежать углероду как в $\mathrm{sp}^{3}$-гибридизации, так и в $\mathrm{sp}^{2}$-гибридизации и отвечает продуктам кислотной деструкции целлюлозы, а также углеводородным загрязнениям ее поверхности. Причем наибольшее увеличение вклада компоненты $\mathrm{C}_{1}$ наблюдается у сульфатированной МКЦ из соломы пшеницы, что, по-видимому, связано с пониженным содержанием кристаллической части в исходной целлюлозе (СК 0,66). Благодаря плотной упаковке кристаллические участки целлюлозного волокна менее доступны для деструктирующего агента [14], а аморфные области целлюлозы наиболее подвержены деградации в кислой среде [15].

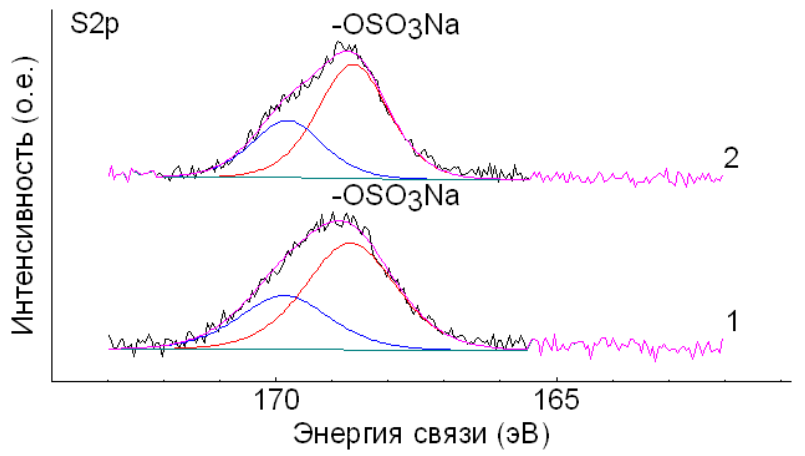

Рис. 4. РФЭС спектры 2p линий серы сульфатированных образцов МКЦ из соломы пшеницы (1 - порошок, 2 - пленка)

Рис. 6. РФЭС спектр 2p линии серы сульфатированного образца промышленной МКЦ (порошок)

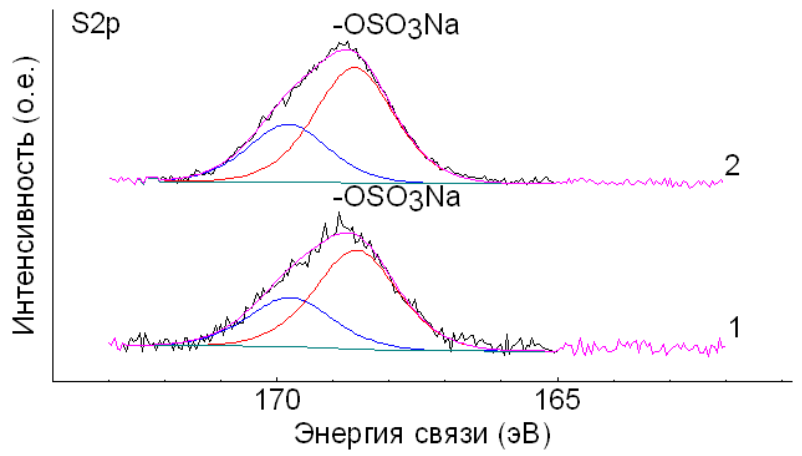

Рис. 5. РФЭС спектры 2p линий серы сульфатированных образцов МКЦ из древесины осины (1 - порошок, 2 - пленка)

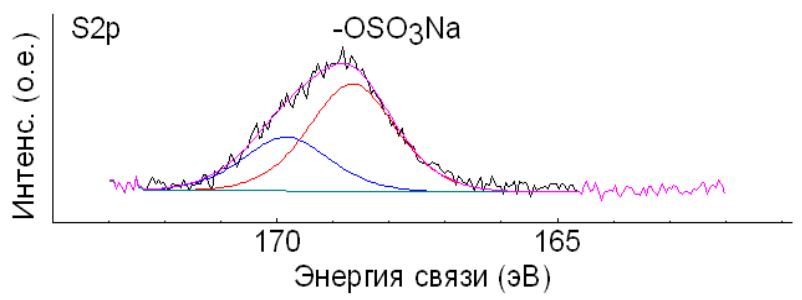




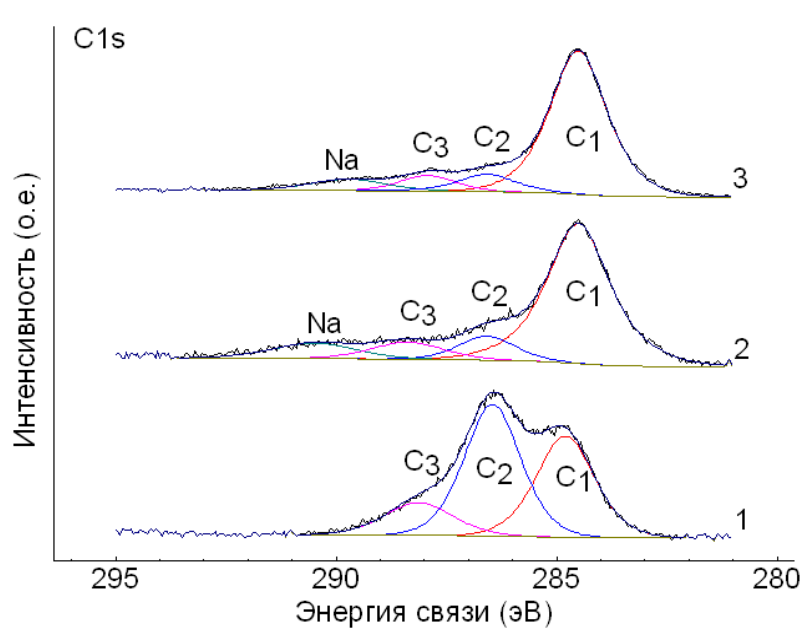

Рис. 7. РФЭС спектры 1s линий углерода исходной МКЦ из соломы пшеницы (1) и сульфатированных образцов МКЦ из соломы пшеницы (2 - порошок, 3 - пленка)

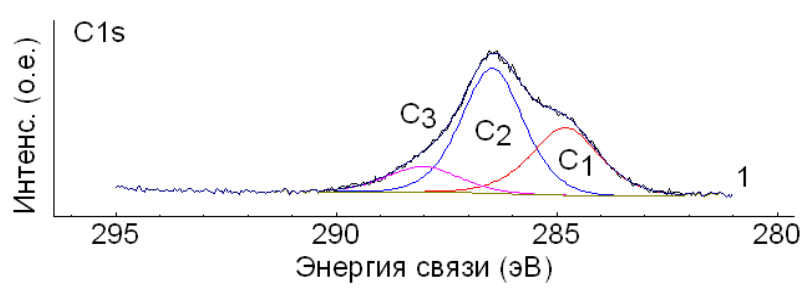

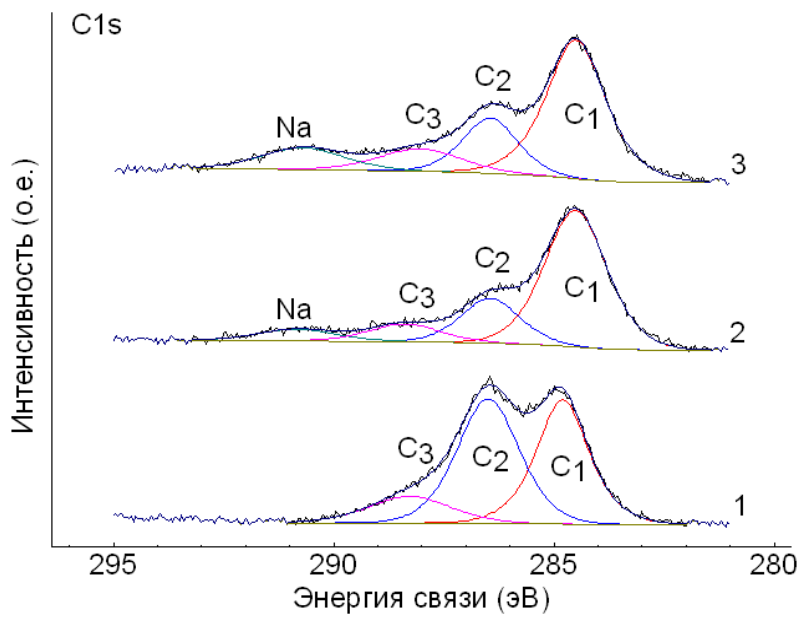

Рис. 8. РФЭС спектры 1s линий углерода исходной МКЦ из древесины осины (1) и сульфатированных образцов МКЦ из древесины осины (2 - порошок, 3 - пленка)

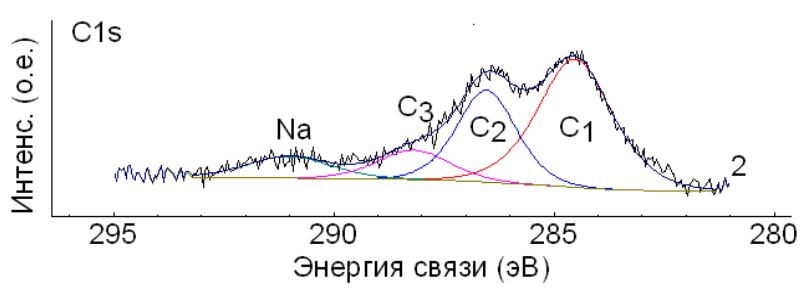

Рис. 9. РФЭС спектры 1s линий углерода промышленной МКЦ (1) и сульфатированного образца промышленной МКЦ (2)

Таблица 4. Результаты разложения РФЭС спектров 1s линий углерода

\begin{tabular}{l|c|c|c|c|c|c}
\hline \multicolumn{1}{c|}{ Образец } & \multicolumn{2}{c|}{$\mathrm{C}_{1}$} & \multicolumn{2}{c|}{$\mathrm{C}_{2}$} & \multicolumn{2}{c}{$\mathrm{C}_{3}$} \\
\cline { 2 - 7 } & эВ & $\%$ & эВ & $\%$ & эВ & $\%$ \\
\hline МКЦ из соломы пшеницы & 284,8 & 38 & 286,5 & 48 & 288,1 & 14 \\
МКЦ из древесины осины & 284,8 & 41 & 286,5 & 46 & 288,3 & 13 \\
Промышленная МКЦ & 284,8 & 33 & 286,5 & 54 & 288,0 & 13 \\
Сульфат МКЦ из соломы пшеницы & 284,5 & 79 & 286,6 & 11 & 288,3 & 10 \\
Пленка сульфата МКЦ из соломы пшеницы & 284,5 & 82 & 286,6 & 10 & 288,0 & 8 \\
Сульфат МКЦ из древесины осины & 284,5 & 69 & 286,4 & 21 & 288,3 & 10 \\
Пленка сульфата МКЦ из древесины осины & 284,5 & 64 & 286,4 & 22 & 288,0 & 14 \\
Сульфат промышленной МКЦ & 284,5 & 56 & 286,5 & 32 & 288,2 & 12 \\
\hline
\end{tabular}

\section{Заключение}

Методом РФЭС показано, что при взаимодействии МКЦ с сульфатирующим агентом происходит введение сульфатной группы в структуру целлюлозы. Содержание серы в поверхностном слое сульфатированной МКЦ из соломы пшеницы составляет 4,0-5,6\% ат., сульфатированной МКЦ из древесины осины - 7,5-9,7\% ат., а сульфатированной промышленной МКЦ - 7,9\% ат.

Спектры 2p линий серы имеют одинаковый вид для всех образцов сульфатированной МКЦ, соответствующий сульфатной форме. Другие формы серы не были обнаружены.

На основании сравнительного анализа объемного (химический анализ) и поверхностного (РФЭС) содержания серы сделан вывод об однородном распределении атомов серы в образцах СЦ из древесины осины и промышленной МКЦ, а также пониженным ее содержанием на поверхности сульфатов МКЦ из соломы пшеницы 
Различие в форме 1s линий углерода в спектрах образцов исходной и сульфатированной МКЦ указывает на изменение химического состояния части атомов углерода при сульфатировании. При разложении спектров $1 \mathrm{~s}$ линии углерода выделены три формы углерода, находящегося в составе различных кислородсодержащих групп.

\section{Благодарности}

В работе использованы приборы Красноярского регионального центра коллективного пользования СО РАН. Авторы выражают благодарность доктору хим. наук Юрию Леонидовичу Михлину за содействие в регистрации и интерпретации данных рентгеновской фотоэлектронной спектроскопии (РФЭС).

\section{Сиисок литературы}

1. Петропавловский Г.А. Гидрофильные частично замещенные эфиры целлюлозы и их модификация путем химического сшивания. Л., 1988. 298 с.

2. Yang J, Du Y, Huang R, Wan Y, Wen Y. The structure-anticoagulant activity relationships of sulfated lancquer polysaccharide: effect of carboxyl group and position of sulfation // Int. J. Biol. Macromol. 2005. Vol. 36, N1-2. Pp. 9-15.

3. Торлопов М.А., Демин В.А. Сульфатированные и карбоксиметилированные производные микрокристаллической целлюлозы // Химия растительного сырья. 2007. №3. С. 55-61.

4. Wang Z.M., Li L, Zheng B.S., Normakhamatov N., Guo S.Y. Preparation and anticoagulation activity of sodium cellulose sulfate // Int J. Biol. Macromol. 2007. Vol. 41, N4. Pp. 376-382.

5. Левданский В.А., Левданский А.В., Кузнецов Б.Н. Сульфатирование микрокристаллической целлюлозы хлорсульфоновой кислотой в диоксане // Химия растительного сырья. 2002. №1. С. 39-44.

6. Калинина Т.Б., Дрозд Н.Н., Кузнецова С.А. и др. Влияние структурных параметров сульфата целлюлозы, выделенной из соломы Triticum aestivum L., на антикоагулянтную активность // Гематология и трансфузиология. 2011. Т. 56, №6. С. 33-38.

7. Савчик Е.Ю., Дрозд Н.Н., Кузнецова С.А. и др. Влияние антикоагулянтной активности сульфатов целлюлозы, выделенной из древесины Populus Tremula, на подвижность в электрическом поле преципитатов с сульфатом протамина // Вопросы биологической, медицинской и фармацевтической химии. 2012. №12. С. 46-54.

8. Groth T., Wagenknecht W. Anticoagulant potential of regioselective derivatized cellulose // Biomaterials. 2001. Vol. 22, N20. Pp. 2719-2729.

9. Патент 2203995 (РФ). Способ получения микрокристаллической целлюлозы / В.Г. Данилов, О.В. Яценкова, С.А. Кузнецова, Б.Н. Кузнецов. 10.05.2003.

10. Патент 2312110 (РФ). Способ получения микрокристаллической целлюлозы из соломы злаковых / Б.Н. Кузнецов, В.Г. Данилов, О.В. Яценкова, Е.Ф. Ибрагимова. 10.12.2007.

11. Черонис Н.Д., Ма Т.С. Микро- и полумикрометоды органического функционального анализа. М., 1973. 576 с.

12. Колесников М.П. Формы кремния в растениях // Успехи биологической химии. 2001. Т. 41. С. 301-332.

13. Hon D. ESCA study of oxidized wood surfaces // Journal of Applied Polymer Science. 1984. Vol. 29, N9. Pp. $2777-2784$.

14. Баттиста О.А. Микрокристаллическая целлюлоза // Целлюлоза и ее производные. Под ред. Н. Байклза, Л. Сегала. М., 1974. Т. 2. С. 412-423.

15. Азаров В.И., Буров А.В., Оболенская А.В. Химия древесины и синтетических полимеров: учебник для вузов. СПб., 1999. 628 с. 
Romanchenko A.S. ${ }^{1}$, Levdansky A.V. ${ }^{1}$, Levdansky V.A. ${ }^{1,2}$, Kuznetsov B.N. ${ }^{1,2 *}$ STUDY OF CELLULOSE SULFATES BY X-RAY PHOTOELECTRON SPECTROSCOPY

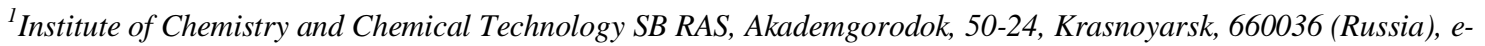
mail: inm@icct.ru

${ }^{2}$ Siberian Federal University, pr. Svobodny, 79, Krasnoyarsk, 660041 (Russia)

Samples of microcrystalline cellulose (MCC) were studied using X-ray photoelectron spectroscopy before and after sulfation. It was established, that the reaction of MCC with chlorosulfonic acid in dioxane solvent results in an introduction of sulfate groups into cellulose structure. The sulfur content in sulfated MCC is varied between 4,0-9,7 \% atomic and the sulfur is present in a form of sulfate. The content of sulfur on the surface and into the bulk of MCC sulfates was compared. The observed difference in shapes of $1 \mathrm{~s}$ lines of carbon in spectra of initial and sulfated MCC samples points on the change of the electron state of a part of carbon atoms after sulfation.

Keywords: microcrystalline cellulose, sulfation, chlorosulfonic acid, dioxane, cellulose sulfates, electron spectroscopy for chemical analysis.

\section{References}

1. Petropavlovskii G.A. Gidrofil'nye chastichno zameshchennye efiry tselliulozy i ikh modifikatsiia putem khimicheskogo sshivaniia. [Hydrophilic partially substituted cellulose ethers and their modification by chemical crosslinking.]. Leningrad, 1988, 298 p. (in Russ.).

2. Yang J, Du Y, Huang R, Wan Y, Wen Y. Int. J. Biol. Macromol., 2005, vol. 36, no. 1-2, pp. 9-15.

3. Torlopov M.A., Demin V.A. Khimiia rastitel'nogo syr'ia, 2007, no. 3, pp. 55-61. (in Russ.).

4. Wang Z.M., Li L, Zheng B.S., Normakhamatov N., Guo S.Y. Int J. Biol. Macromol., 2007, vol. 41, no. 4, pp. $376-382$.

5. Levdanskii V.A., Levdanskii A.V., Kuznetsov B.N. Khimiia rastitel'nogo syr'ia, 2002, no. 1, pp. 39-44. (in Russ.).

6. Kalinina T.B., Drozd N.N., Kuznetsova S.A. Gematologiia i transfuziologiia, 2011, vol. 56, no. 6, pp. 33-38. (in Russ.).

7. Savchik E.Iu., Drozd N.N., Kuznetsova S.A. Voprosy biologicheskoi, meditsinskoi i farmatsevticheskoi khimii, 2012, no. 12, pp. 46-54. (in Russ.).

8. Groth T., Wagenknecht W. Biomaterials, 2001, vol. 22, no. 20, pp. 2719-2729.

9. Patent 2203995 (RU). 10.05.2003. (in Russ.).

10. Patent 2312110 (RU). 10.12.2007. (in Russ.).

11. Cheronis N.D., Ma T.S. Mikro- i polumikrometody organicheskogo funktsional'nogo analiza. [Micro- and polumikrometody organic functional analysis]. Moscow, 1973, 576 p. (in Russ.).

12. Kolesnikov M.P. Uspekhi biologicheskoi khimii, 2001, vol. 41, pp. 301-332. (in Russ.).

13. Hon D. Journal of Applied Polymer Science, 1984, vol. 29, no. 9, pp. 2777-2784.

14. Battista O.A. Tselliuloza i ee proizvodnye. [Cellulose and its derivatives.]. Ed. N. Baiklz, L. Segal. Moscow, 1974, vol. 2, pp. 412-423. (in Russ.).

15. Azarov V.I., Burov A.V., Obolenskaia A.V. Khimiia drevesiny i sinteticheskikh polimerov. [Wood chemistry and synthetic polymers.]. St. Petersburg, 1999, 628 p. (in Russ.).

\footnotetext{
* Corresponding author.
} 